\title{
MORPHOLOGICAL INTEGRATION OF NATIVE SOUTH AMERICAN UNGULATE MANDIBLES. A TRIBUTE TO D'ARCY THOMPSON IN THE CENTENNIAL OF "ON GROWTH AND FORM"
}

\author{
GUILLERMO H. CASSINI $1,2,4$ \\ NAHUEL A. MUÑOZ3,4 \\ SERGIO F. VIZCAIINO3,4
}

\begin{abstract}
'División Mastozoología, Museo Argentino de Ciencias Naturales "Bernardino Rivadavia", Av. Ángel Gallardo 470, Ciudad Autónoma de Buenos Aires, C1405DJR, Argentina.

2Departamento de Ciencias Básicas, Universidad Nacional de Luján, Ruta 5 y Av. Constitución, Luján, 6700, Buenos Aires, Argentina.

${ }^{3}$ División Paleontología Vertebrados, Museo de La Plata, Unidades de Investigación Anexo Museo, FCNyM-UNLP, 60 y 122,1900 La Plata, Argentina.

${ }^{4}$ Consejo Nacional de Investigaciones Científicas y Técnicas (CONICET).
\end{abstract}

Recibido: 15 de octubre 2017 - Aceptado: 7 de diciembre 2017

Para citar este artículo: Guillermo H. Cassini, Nahuel A. Muñoz, Sergio F. Vizcaíno (2017). Morphological integration of native South American ungulate mandibles. A tribute to D'Arcy Thompson in the centennial of "On growth and form". Publicación Electrónica de la Asociación Paleontológica Argentina 17 (2): 58-74.

Link a este artículo: http://dx.doi.org/10.5710/PEAPA.07.12.2017.253

DESPLAZARSE HACIA ABAJO PARA ACCEDER AL ARTÍCULO

Otros artículos en Publicación Electrónica de la APA 17(1):

\section{Patterer, Zucol \& Passeggi}

ANÁLISIS FITOLITICOS EN SUELOS FORMADOS SOBRE ANTIGUAS TERRAZAS DEL RÍO URUGUAY (COLÓN, ENTRE RÍOS): PRIMERA EVIDENCIA DE RETRACCIÓN DE LOS PALMARES DE BUTIA YATAY (MART.). BECC.

\section{Vizcaíno et al.}

ON AN ALBUM OF PHOTOGRAPHS RECORDING FOSSILS IN THE "OLD COLLECTIONS" OF THE MUSEO DE LA PLATA AND AMEGHINO'S PRIVATE COLLECTION AT THE BEGINNING OF THE XXTH CENTURY

Asociación Paleontológica Argentina Maipú $6451^{\circ}$ piso, C1006ACG, Buenos Aires República Argentina

Tel/Fax (54-11) 4326-7563 Web: www.apaleontologica.org.ar

\section{Deschamps et al.}

BIOSTRATIGRAPHIC REASSIGNMENT OF THE NEOGENE CAENOLESTINES (MARSUPIALIA) OF THE PAMPEAN REGION: THE CASE OF PLIOLESTES TRIPOTAMICUS REIG, 1955 


\title{
MORPHOLOGICAL INTEGRATION OF NATIVE SOUTH AMERICAN UNGULATE MANDIBLES. A TRIBUTE TO D'ARCY THOMPSON IN THE CENTENNIAL OF "ON GROWTH AND FORM"
}

\author{
GUILLERMO H. CASSINI1,2,4, NAHUEL A. MUÑOZ3,4, AND SERGIO F. VIZCAÍNO3,4
}

\author{
1División Mastozoología, Museo Argentino de Ciencias Naturales "Bernardino Rivadavia", Av. Ángel Gallardo 470, Ciudad Autónoma de Buenos Aires, C1405DJR, \\ Argentina.gcassini@macn.gov.ar \\ ²Departamento de Ciencias Básicas, Universidad Nacional de Luján, Ruta 5 y Av. Constitución, Luján, 6700, Buenos Aires, Argentina. \\ ${ }^{3}$ División Paleontología Vertebrados, Museo de La Plata, Unidades de Investigación Anexo Museo, FCNyM-UNLP, 60 y 122,1900 La Plata, Argentina. \\ nahuelmunoz@fcnym.unlp.edu.ar; vizcaino@fcnym.unlp.edu.ar \\ ${ }^{4}$ Consejo Nacional de Investigaciones Científicas y Técnicas (CONICET).
}

\begin{abstract}
South American native ungulates include several extinct lineages that evolved within the context of South American Cenozoic geographic isolation. By the late-early Miocene Santacrucian, the orders Notoungulata, Litopterna, and Astrapotheria were differentiated. Recent ecomorphological studies highlighted complex functional patterns between their habitat/diet and hypsodonty. In order to understand these relationships in an evolutionary context we used geometric morphometrics methods (27 3-D landmarks) to evaluate the morphological integration of two of the primary functional units of the mandible: the alveolar region and the ascending ramus. Principal component analyses (PCA) and two blocks Partial Least Squares analyses (PLS) were used to explore the patterns of variation and covariation between these two modules. The main variation in shape is related to the robusticity and curvature of the mandibular corpus, and the relative size of the angular and coronoid process. The PLS analyses show a very strong morphological integration within the Litopterna, but a pattern of modularity in the Notoungulata. There is a common pattern of covariation in Astrapotheria and Litopterna, which might be due to similar constraints. The different covariation patterns in notoungulates with respect to litopterns are in concordance with both the taxonomic and morphological diversity of the clades, particularly in the typotheres. The modularity present in notoungulates could have allowed specializations in each module of the mandible, related to crown height or muscle attachments, without a high morphological constrain. This could have resulted in their high morphological diversity, in contrast with the more conservative morphology present in litopterns.
\end{abstract}

Key words. Notoungulata. Litopterna. Santacrucian. Geometric Morphometrics. D'Arcy Thompson. Modularity.

Resumen. INTEGRACIÓN MORFOLÓGICA DE LA MANDÍBULA DE LOS UNGULADOS NATIVOS DE AMÉRICA DEL SUR. UN TRIBUTO A D’ARCY THOMPSON EN EL CENTENARIO DE "SOBRE EL CRECIMIENTO Y LA FORMA". Los ungulados nativos de América del Sur incluyen varios linajes extintos que evolucionaron en el contexto de aislamiento geográfico del Cenozoico sudamericano. Durante el Santacrucense (Mioceno temprano), los órdenes Notoungulata, Litopterna y Astrapotheria ya estaban diferenciados. Los estudios ecomorfológicos recientes destacaron patrones funcionales complejos entre hábitat/dieta e hipsodoncia en estos grupos. Se analizan estas relaciones en un contexto evolutivo, utilizando métodos morfogeométricos (27 landmarks 3-D) para evaluar la integración morfológica de dos de las unidades funcionales principales de la mandíbula: región alveolar y rama ascendente. Para explorar los patrones de variación y covariación entre estos dos módulos, se utilizaron Análisis de componentes principales (PCA) y Análisis de mínimos cuadrados parciales de dos bloques (PLS). La variación principal de forma está relacionada con la robustez y la curvatura del cuerpo mandibular y el tamaño relativo de los procesos angular y coronoides. Los PLS muestran una integración morfológica muy fuerte en Litopterna y un patrón de modularidad en Notoungulata. Existe un patrón común de covariación en Astrapotheria y Litopterna que podría deberse a restricciones similares. Los diferentes patrones de covariación en notoungulados con respecto a los litopternos están en concordancia con la diversidad taxonómica y morfológica de los clados, particularmente en los tipoterios. La modularidad presente en Notoungulata habría permitido especializaciones en cada módulo de la mandíbula, relacionadas con la altura de la corona o las inserciones musculares, sin una alta restricción morfológica. Esto podría haber resultado en su alta diversidad morfológica, en contraste con la morfología más conservadora presente en Litopterna.

Palabras clave. Notoungulata. Litopterna. Santacrucense. Morfometría Geométrica. D’Arcy Thompson. Modularidad. 
A CENTURY ago, in his book "On growth and form", D'Arcy Thompson (1917) tried to convince morphologists on the need of mathematical assistance in investigating the biological form. Its chapter 17, "On the Theory of Transformations, or the Comparison of Related Forms", greatly inspired geometric morphometrics, which over the last twenty-five years has put together geometry, multivariate morphometrics, computer science, and visualization imaging techniques, making the D'Arcy Thompson's task eventually accomplished (see Adams et al., 2013; Cardini and Loy, 2013). The best known examples of transformation series provided by D'Arcy Thompson (1917) where based on extant species, like the series from the porcupine-fish Diodon Linnaeus, 1758 to the sunfish Orthagoriscus (=Mola) mola (Linnaeus, 1758) (Thompson, 1917: figs. 525-526) or that from the human to chimpanzee skull (Thompson, 1917: figs. 548-550). However, there are also several iconic paleontological examples including the Jurassic bird Archaeopteryx Meyer, 1861 and the Cretaceous crocodylomorph Notosuchus Woodward, 1896, among others. Nevertheless, most remarkable is the attention given to the transformations of the extinct and extant Rhinocerotidae, their comparison with tapirs and the transformation from Oligocene to modern Equidae. Recently, based on molecular evidence (e.g., Welker et al., 2015), it was proposed that the Perissodactyla (i.e., rhinos, tapirs, and horses) share a common ancestor with at least two taxa of "the strangest animals ever discovered" (sensu Darwin, 1845), also known as the South American native ungulates (SANU). The SANU include several extinct lineages that evolved within the context of South American Cenozoic geographic isolation (see below). Recent ecomorphological analyses highlighted the existence of complex functional pattern related to habitat/diet and tooth dimensions in extant and extinct ungulates, including SANU. In this contribution, we aim to honor D'Arcy Thompson's pioneering intellectual work studying these complex relationships in an evolutionary context, using geometric morphometrics methods to evaluate the morphological integration of the mandible in the Santacrucian SANU.

\section{SANU}

Several extinct South American native ungulate lineages evolved within the geographical context of isolation during much of the Cenozoic. By the late-early Miocene Santacrucian Age, an interval best documented from the Santa Cruz Formation in Southern Patagonia, to the east of the Andes, the orders Notoungulata, Litopterna, and Astrapotheria (Fig. 1) were clearly differentiated and are among the most abundant mammals of this formation. Cassini et al. (2012a) provided an updated description of the diversity of Santacrucian ungulates of the Santa Cruz Formation on, or near, the Atlantic coast of the Santa Cruz Province, which has provided the best specimens for anatomical and paleobiological studies (Vizcaíno et al., 2012). They are represented by Notoungulata (Adinotherium Ameghino, 1887a, Nesodon Owen, 1846 [Fig. 1.1], Interatherium Ameghino, 1887b [Fig. 1.2], Protypotherium Ameghino, 1887b, Hegetotherium Ameghino, 1887a and Pachyrukhos Ameghino, 1885), Litopterna (Theosodon Ameghino, 1887a, Anisolophus Burmeister, 1885, Tetramerorhinus Ameghino, 1894, Diadiaphorus Ameghino, 1887a [Fig. 1.3] and Thoatherium Ameghino, 1887a), and Astrapotheria (Astrapotherium Burmeister, 1879; Fig. 1.4). Among them, notoungulates present the highest diversity of size and morphology. Consequently, they were object of numerous studies on body mass estimations (Croft, 2001; Scarano et al., 2011; Cassini et al., 2012b; Elissamburu, 2012), ecomorphological characterizations (Elissamburu, 2004, 2010; Croft and Anderson, 2008; Cassini et al., 2011, 2012a; Cassini, 2013; Muñoz et al., 2017; Giannini and García-López, 2014), tooth wear and durability (Townsend and Croft, 2008; Billet et al., 2009; Reguero and Prevosti, 2010), biomechanical performance of the masticatory apparatus (Cassini and Vizcaíno, 2012), digestion physiology (Cassini et al., 2012a; Scarano et al., 2011) and the relation of dental morphology to ecological specializations (Cassini et al., 2017; Gomes Rodrigues et al., 2017). Although less diverse, litopterns reached their greatest generic richness during the Santacrucian Age (ViIlafañe et al., 2006). Since Scott (1937), they have been traditionally considered mainly herbivorous inhabitants of open habitats. Perhaps due to their lower diversity and more conservative morphology, their paleobiology has been mostly neglected. However, their three main biological aspects (body mass, substrate preference and use, and feeding; sensu Vizcaíno et al., 2016) have been approached in several recent studies (Cifelli and Guerrero, 1997; Soria, 2001; 
Cassini et al., 2012a,b; Cassini and Vizcaíno, 2012; Cassini, 2013). Astrapotheres are the least diverse among Santacrucian ungulates and include one of the most bizarre forms, colloquially described as morphologically intermediate between a tapir and an elephant (Cassini et al., 2012a and references therein). Their paleobiology has been barely studied, but there are a few ecological reconstructions based on general morphology, enamel structure and morphometrics (Riggs, 1935; Rensberger and Pfretzschner, 1992; Croft, 1999; Cassini et al., 2012a,b; Cassini and Vizcaíno, 2012; Cassini, 2013).

A baseline paleoecological study of the mammalian fauna of the coastal Santa Cruz Formation (Vizcaíno et al., 2010) proposed as a working hypothesis that the coexistence of so many different ungulate lineages implies marked vegetation resource partitioning. Following Cassini (2013 and references therein), the major findings can be summarized as follows. Santacrucian ungulates can be classified into three body size categories: (i) small sized (1-10 kg); (ii) medium-sized (10-100 kg) and (iii) large-sized ungulates (100-1000 kg). Notoungulates were characterized as open habitat dwellers, with some taxa foraging on grass (Protypotherium, Interatherium) and others on grass and leaves (Hegetotherium, Pachyrukhos, and Adinotherium). Nesodon may have dwelled in mixed habitats and had a mixed feeding behavior, while small proterotheriids (Anisolophus and Thoatherium) may have fed predominantly on dicotyledonous plants. The remaining litopterns (Tetramerorhinus, Diadiaphorus, and Theosodon) and Astrapotherium may have foraged in closed habitats and fed on dicotyledonous plants. The relationship between dental occlusal surface and body mass indicates that litopterns, especially proterotheriids, carried out extensive intraoral food processing rather than having relied on a specialized digestive physiology. Conversely, notoungulates, which have lower occlusal surface per unit mass, would have had a better digestive capacity than litopterns.

\section{Morphological integration}

Morphological integration refers to the coordination in size and shape of the different parts of an organism to result on a functional whole (Klingenberg, 2013), and can be traced to the classical morphological studies, being a seminal part of the ideas of Georges Cuvier (Mayr, 1982). A concept closely related to integration is modularity. It refers to the relation between parts (modules) which are tightly integrated internally, but relatively independent from other modules (Klingenberg, 2008).

Morphological integration and modularity can be addressed through the study of the covariation among morphological traits that would reflect the patterns of connectivity between the parts of the network (Klingenberg, 2013). These concepts can be applied in different contexts depending on the level of analysis. The examination of data from different ontogenetic stages of a species could be used on an onto-
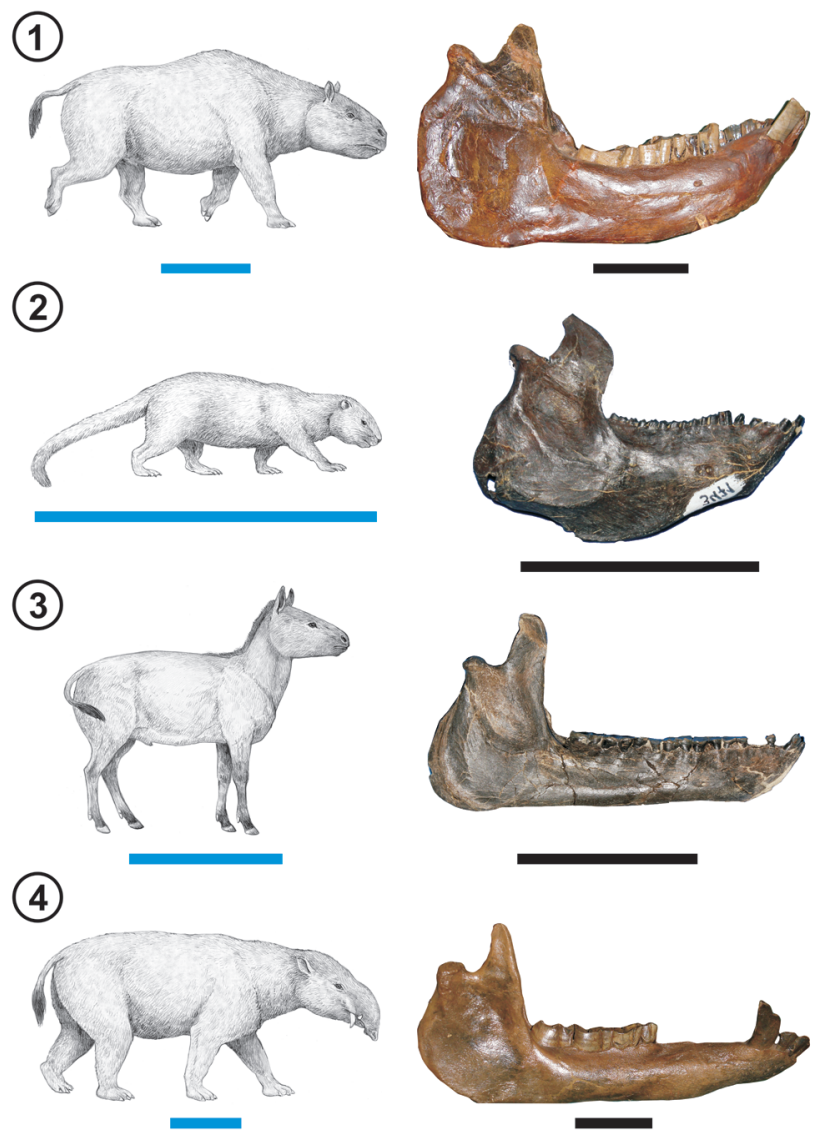

Figure 1. Life reconstructions and mandibles of each Santacrucian ungulate linage.1, Nesodon imbricatus YPM-VPPU 15256; 2, Interatherium robustum MPM-PV 3471; 3, Diadiaphorus majusculus MPM-PV 3397; 4, Astrapotherium magnum AMNH 9278. Life reconstructions scale bars (blue) $=50 \mathrm{~cm}$. Mandibles scale bars (black)=10 cm (except for Interatherium=5 cm). Modified from Vizcaíno et al. (2016). 
TABLE 1 - Mandibular landmarks, names and definitions used in the present study. See also Cassini (2013).

\begin{tabular}{|c|c|c|}
\hline Number & Name & Definition of landmark \\
\hline 1 & Gnathion & Caudo-ventral margin of the mandibular symphysis on the midline. \\
\hline 2 & Infradentale & Alveoli dentalis of 11 in the midline. \\
\hline 3 & & Distal margin of alveoli dentalis of the last lower incisor. \\
\hline 4 & & Distal margin of alveoli dentalis of the lower canine. \\
\hline 5 & & Mesial margin of the alveoli dentale of the first functional premolar. \\
\hline 6 & & Margo interalveolaris between last premolar and first molar. \\
\hline 7 & & Distal margin of the alveoli dentale of the last molar. \\
\hline $8-11$ & semilandmarks & Over the ascending process of ramus mandibulae and processus coronoideus. \\
\hline 12 & Coronion & The most superior point on the processus coronoideus. \\
\hline $13-14$ & semilandmarks & Over caudal margin of processus coronoideus. \\
\hline 15 & Mandibular notch & The most inferior point on the incisura mandibulae. \\
\hline 16 & Condylion lateral & Most medial margin of mandibular condyle. \\
\hline 17 & Condylion medial & Most lateral margin of mandibular condyle. \\
\hline 18 & & Caudal margin mandibular condyle. \\
\hline 19 & & Most dorsal-caudal rugosity from musculus masseter insertion. \\
\hline $20-22$ & semilandmarks & Over caudal-ventral margin of angulus mandibulae. \\
\hline 23 & & Most anterior roughness from musculus masseter insertion. \\
\hline $24-27$ & semilandmarks & Over ventral margin of corpus mandibulae. \\
\hline
\end{tabular}

genetic integration analysis or the study of evolutionary changes; the coordination among parts between related species could help to understand evolutionary integration (Klingenberg, 2008, 2013).

In this work we study the evolutionary integration within the mandible and the modularity between two of its primary functional units, the alveolar region and the ascending ramus, in Santacrucian notoungulates, litopterns, and astrapotheres.

\section{MATERIALS AND METHODS}

\section{Specimens}

We investigated 18 mandibles of Santacrucian ungulates based on their morphological integrity (i.e., with no apparent deformation, as well as landmark availability). Specimens are housed in the paleontological collections of the American Museum of Natural History (AMNH, New York, USA), Museo Argentino de Ciencias Naturales "Bernardino Rivadavia", Ameghino Collection and Santa Cruz Collection (MACN-A and MACN-SC, Buenos Aires, Argentina), Museo Regional Provincial Padre M. Jesús Molina, (MPM-PV, Río Gallegos, Argentina), and Yale Peabody Museum, Vertebrate Paleontology, Princeton University Collection, (YPM-VPPU, New Haven, USA).

\section{Landmark data}

The mandibular shape was quantified by 3D landmark coordinates acquired with a Microscribe G2L digitizer (Im- 
mersion Corporation, San José, California, USA). The dataset is a subset originated from the study of Cassini (2013) and includes: five toxodontids and six typotheres (Notoungulata); four proterotheriids and one macraucheniid (Litopterna); and one astrapothere (Astrapotheria) (see Appendix I). The data consist of 27 mandibular landmarks, including type I (or anatomic), II (or mathematic), and III (or semilandmarks). Cassini (2013) characterized the curves taken more semi-
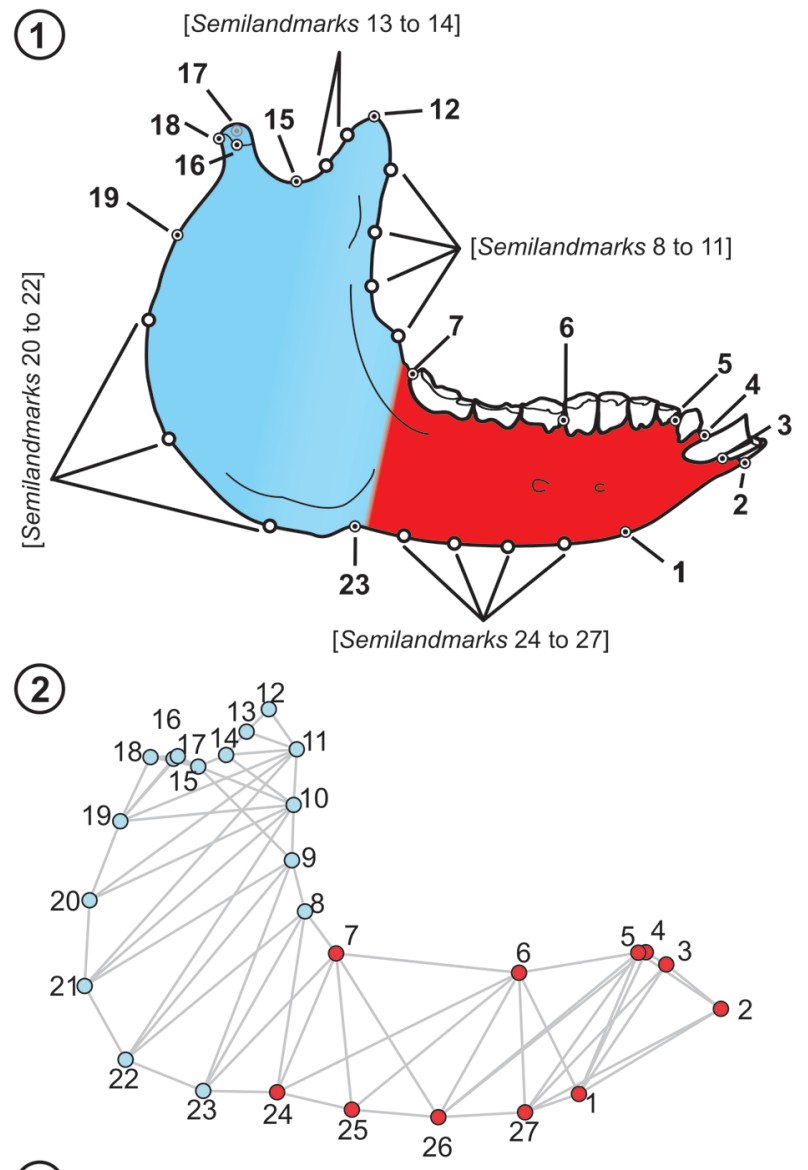

(3)

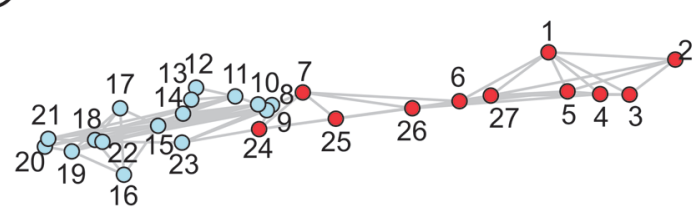

Figure 2. 1, Landmark configuration and partitions (blocks) on Adinotherium mandible. 2-3, Connectivity of landmarks for testing modularity hypothesis on contiguous partitions on lateral norm and occlusal norm. Reference: red, alveolar ramus; blue, ascending ramus. Definitions in Table 1. landmarks than defined, and then reduced in number and equispaced using "resample" software of NYCEP (Reddy et al., 2007). The semilandmarks $L 20$ to $L 22$ characterize the caudal border of the mandibular angle along the masseter scar; L8 to L11 and L13 to L14, the rostral and caudal border of coronoid process, respectively; and L24 to L27, the ventral margin of mandibular corpus (see Tab. 1 and Fig. 2.1).

\section{Geometric morphometrics}

In order to remove the spatial variation that does not correspond to shape, the landmark configurations were superimposed, applying rotation, translation, reflection and scaling transformations, using Generalized Procrustes Analysis (Rohlf, 1990). A principal component analysis (PCA) was carried out on the aligned landmark configurations to search for variation patterns in the whole mandible.

To explore the patterns of covariation between the two primary functional units of the mandible, we define the Block-1 as being composed of the alveolar region (L1-7, L24-27), and the Block-2 of the ascending ramus (L8-23) (Fig 2.1). Here we use two distinct analytical approaches to evaluate modularity: one based on partial least squares (Mitteroecker and Bookstein, 2008) and another based on Escoufier's RV coefficient (Klingenberg, 2009).

The Partial Least Squares analysis (PLS) was used to find correlated pairs of linear combinations between two blocks of landmarks within the configuration. Following Klingenberg (2013), the use of a common shape space for both blocks allows examining the covariation between them in the context of the structure as a whole and taking into account all aspects of covariation, (e.g., relative sizes and arrangement of the parts). Additionally, we used two independent Procrustes fits to analyze the shape covariation of the two blocks (from here on "separate fit analysis"). This approach ignores the anatomical connection of the two blocks, and detects only the shared aspects of covariation between them (Klingenberg, 2009). In these morphometric analyses (PCA and PLS), the results produce vectors in shape space. The difference between both analyses is that PCA accounts for overall variation throughout the entire landmark configuration; while PLS does it on the major covariation between blocks (Klingenberg, 2013). Therefore, in order to compare those variation components (i.e., to 
examine the shape changes similarity between each PC and PLS), we performed an angular comparison of vectors directions. The angles between these vectors were computed as the arccosines of the inner products between them, and compared under the null hypothesis of orthogonality (Drake and Klingenberg, 2008; Klingenberg and Marugán-Lobón, 2013). When these angles are close to zero then both analyses are similar and consequently share a similar shape change.

The hypothesis of modularity between the two blocks was tested by means of the Escoufier's RV coefficient. This coefficient was introduced by Klingenberg (2009) to quantify the strength of covariation between blocks. The RV coefficient could be interpreted as a multivariate generalization of the squared correlation coefficient that allows evaluating whether an a priori partitioning of landmarks, with a defined connectivity network (Fig. 2.2 and 2.3), exhibits the expected covariation under the null hypothesis of modularity.
To evaluate the morphological integration in an evolutionary context and avoid biases due to better representation of some species in the sample (e.g., Nesodon and Interatherium), we worked on the averaged species configurations. Consequently, when the identified modularity relates to constraints (or lack thereof), in the sense of hindering more diversification through the biased generation of variation, the interpretations refer to a macroevolutionary integration and modularity, instead of being measured at the population level.

Additionally, we evaluated the morphological integration on the notoungulates and litopterns separately. A symmetrical Procrustes rotation was used to compare the similarities of two ordinations (PLS scores) of these subsets regarding the averaged species analyses. Procrustes rotation uses uniform scaling and rotation to minimize the squared differences between two ordinations. The significance was assessed by permutation of the complete enu-

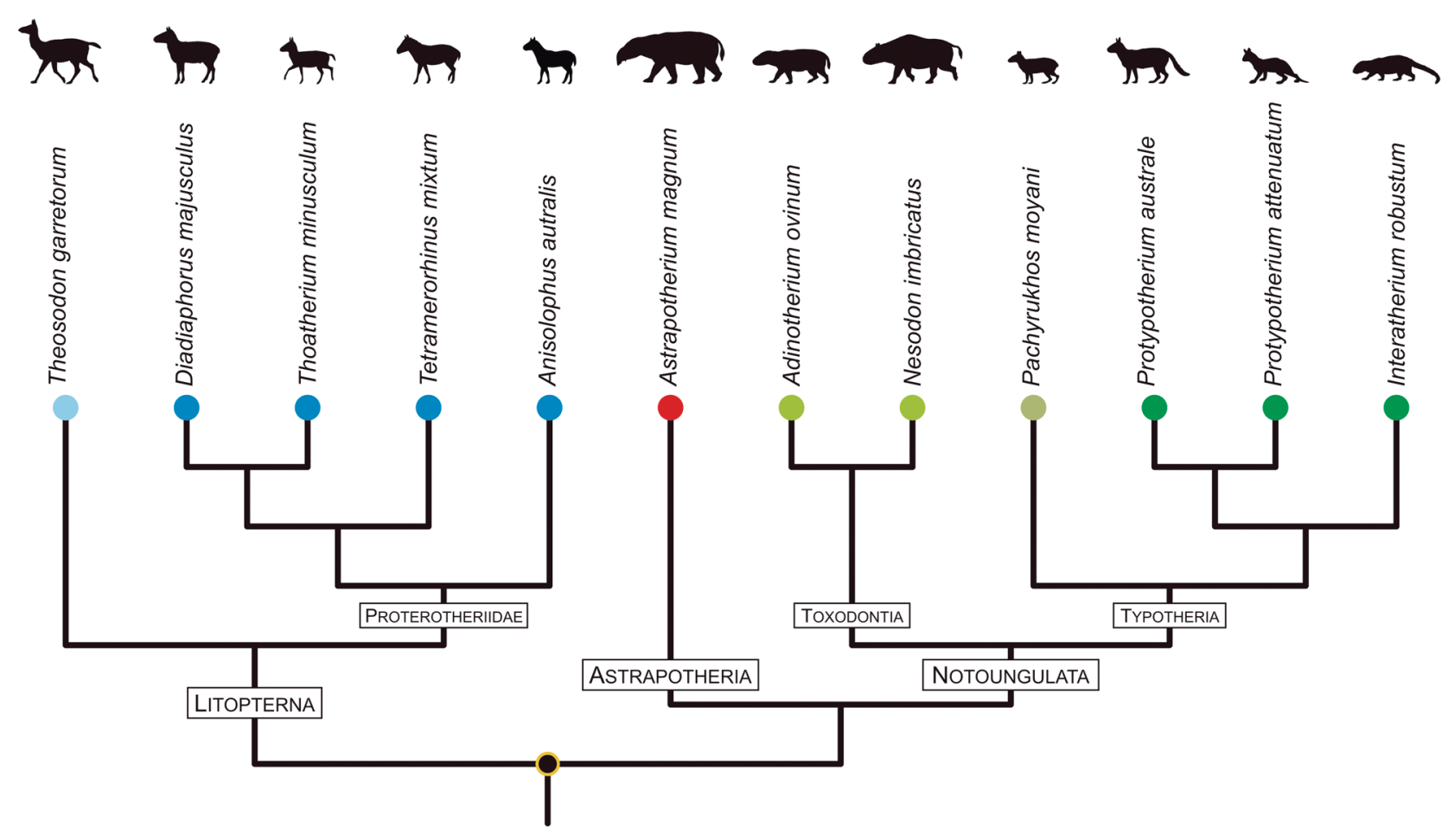

Figure 3. Phylogenetic tree including the sampled Santacrucian native ungulate species, based on Nasif et al. (2000), Billet (2010, 2011), Reguero and Prevosti (2010) and Schmidt (2015). Reference: Astrapotheria: red circle, Litopterna: blue range circles, Notoungulata: green range circles. 
meration on Vegan 2.4-3 package in R 3.4.1 (Oksanen et al., 2017; R Development Core Team, 2017). Finally, for the two clades (Notoungulata and Litopterna) morphological disparity (MD) was considered in order to compare their diversity. Following Zelditch et al. (2004), MD was calculated as the trace of the covariance matrix of the principal component scores (see also, Wilson, 2013; Echarri and Prevosti, 2015). The $95 \%$ confidence intervals for each MD were estimated using a jackknife procedure (Quenouille, 1956), reporting results from untrimmed (full set of jackknife pseudovalues used) and trimmed (with the smallest pseudovalues removed in the calculations) confidence intervals (Manly, 2006).

To assess the influence of phylogenetic signal, the analyses above were repeated using a phylogenetic comparative method. In doing so, a tree representing the phylogenetic relationships of the species of the sample was built based on phylogenetic hypotheses available in the literature (Nasif et al., 2000; Billet, 2010, 2011; Reguero and Prevosti, 2010; Schmidt, 2015). The reconstructed phylogenetic tree (Fig. 3) was projected into the tangent shape space of the PC scores computed from the mandibular averaged configurations to explore the morphospaces occupied by each clade. The ancestral states of internal nodes were reconstructed based on squared-change parsimony (Maddison, 1991). Evolutionary integration between the two blocks was studied with PCA and PLS on the independent contrasts (Bastir et al., 2010; Klingenberg and Marugán-Lobón, 2013). In the same way, the modularity hypothesis was tested computing the RV coefficient, using the covariance matrices obtained from independent contrasts (Drake and Klingenberg, 2010).

All the morphometrics were performed on MorphoJ 1.06b software (Klingenberg, 2011). In addition, significance of all analyses was assessed by 10000 rounds of permutation tests. Visualization and graphics were made using the Morpho R package 2.5.1 (Schlager, 2017).

\section{RESULTS}

\section{Species variation}

The PCA of averaged species (PCA $w$ ) resulted in five PCs accounting for nearly $90 \%$ of the total variation. PCw1 explained $\sim 49 \%$ of the total variance, and PCw2 and PCw3

about $13 \%$ and $11 \%$, respectively. These three PCs account for most of the $70 \%$ cumulative variance. The shape changes associated to the first two eigenvectors are shown in Figure 4. Only the shape changes associated with the first eigenvector were similar to the corresponding PCs from Cassini (2013) with an angle between vectors of $32.407^{\circ} ; \mathrm{p}<0.00001$ after 10000 rounds of permutation tests. It ranges from a robust, curved mandibular corpus and expanded coronoid and angular processes on the negative end, to a gracile, straight mandibular corpus and reduced coronoid and angular

(1)

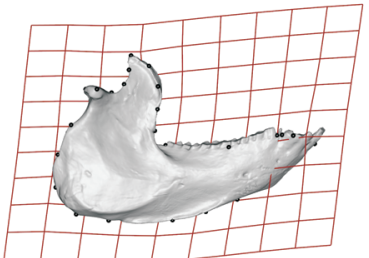

negative $P C w 1$

(2)

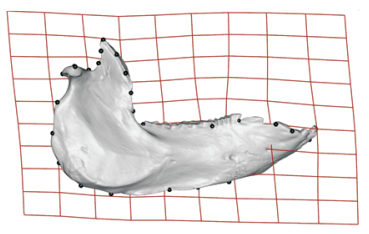

negative $\mathrm{PCw} 2$

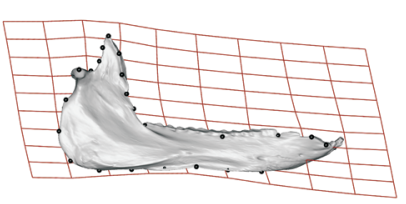

positive PCw1

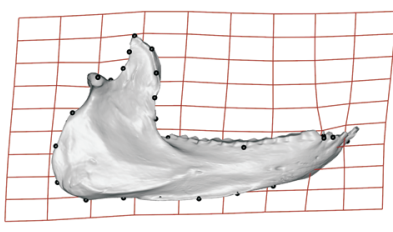

ars positive PCw2

(3)

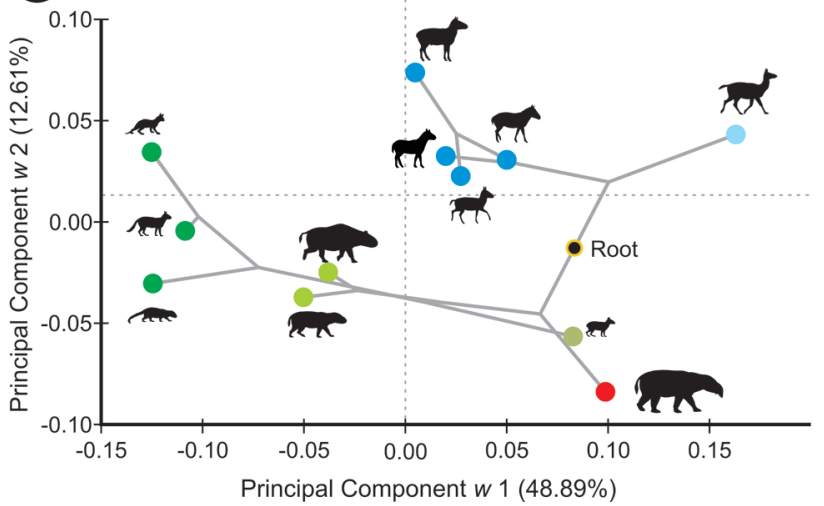

Figure 4. PCA w of Santacrucian ungulate specimens. 1-2, thin plate spline gridlines of mandibular shape (lateral norm) of: 1, most negative and positive first component; 2 , most negative and positive second component; 3 , taxa distribution on the morphospace depicted by the two first PC. Reference: Astrapotheria: red circle, Litopterna: blue range circles, Notoungulata: green range circles; phylogenetic mapping: grey line; silhouettes as in Figure 3. 
processes on the positive end (Fig. 4.1). The PCw2 represents shape changes mainly associated with a robust alveolar region and gracile angular region on negative values, and a gracile alveolar regions and a more developed angular region towards positive ones. These changes include a large diastema and short premolar tooth row plus a less developed coronoid and angular processes on negative values (Fig. 4.2). On the positive side, there is no diastema with large premolar tooth row plus a well-developed coronoid and angular processes. The notoungulates, except for Pachyrukhos, clusters on the negative side on PCw1 (Fig. 4.3). Pachyrukhos is located on the positive side on PCW1 and negative side on PCW2. The interatheriids are close to zero on PCW2 and the nesodontines Adinotherium and $\mathrm{Ne}$ sodon have negative values on PCW2. Among Litopterna, proterotheriids have low positive values on PCw1, but high on PCw2. In contrast, Theosodon garretorum lies on high positive values on PCW1 but low on PCw2. The astrapothere clusters close to Pachyrukhos with intermediate values on PCw1 between proterotheriids and Theosodon, but has the most negative value on PCW2. In this morphospace, the whole sample has a morphological disparity (MDw) of 0.0174 (whit $0.0168-0.0181$ and $0.0170-0.0182$; untrimmed and trimmed 95\% confidence intervals, respectively). The notoungulates have a higher morphological disparity than the litopterns (MDn 0.0154 vs. MDI 0.00968). The untrimmed $95 \%$ confidence intervals for these two clades (CIn 0.01268-0.01809 and CII 0.00618-0.01319) showed a small superposition ( 0.00051). On the contrary, the trimmed $95 \%$ confidence intervals of notoungulates and litopterns showed no superposition (CIn 0.01549-0.01732 and Cll 0.009328-0.01245, respectively).

The reported results were consistent when the analyses were repeated on the independent contrast (see supplementary material 01). The PCA on the independent contrast (PCAic) resulted in five PCs accounting for nearly $85 \%$ of the total variation. PCic1 explained $\sim 42 \%$ of the total variance, and PCic2 and PCic3 about 16\% and 13\%, respectively. These three PCs account for most of the $71 \%$ cumulative variance. The shape changes associated to the first eigenvector were similar to the PCW1 with an angle between vectors of $20.68^{\circ}, \mathrm{p}<0.00001$ after 10000 rounds of permutation tests.

TABLE 2 - Mandibular Partial Least Squares analyses for each data set.

\begin{tabular}{|c|c|c|c|c|c|c|}
\hline Data set & Pair of axes & Singular value & S.v. p-value & $\%$ Total covar. & Correlation & Corr. p-value \\
\hline \multirow{2}{*}{ Species averaged } & PLSW1 & 0.00407 & $<0.0001$ & 87.87 & 0.931 & 0.0020 \\
\hline & PLSW2 & $0.00092 *$ & 0.8073 & 4.51 & 0.898 & 0.0114 \\
\hline \multirow{2}{*}{ Independent contrast } & PLSic1 & 0.00162 & $<0.0001$ & 79.83 & 0.936 & 0.0094 \\
\hline & PLSic2 & $0.00058 *$ & 0.1859 & 10.13 & 0.932 & 0.0212 \\
\hline \multirow{2}{*}{ Notoungulata } & PLSn1 & 0.00398 & 0.0393 & 85.09 & $0.881^{*}$ & 0.2022 \\
\hline & PLSn2 & $0.00139 *$ & 0.0934 & 10.37 & $0.896^{*}$ & 0.2073 \\
\hline \multirow{2}{*}{ Litopterna } & $P L S / 1$ & 0.00319 & $<0.0001$ & 91.57 & 0.984 & 0.0320 \\
\hline & PLSI2 & $0.00084 *$ & 0.7213 & 6.39 & $0.961 *$ & 0.0498 \\
\hline \multirow{2}{*}{ Cassini (2013) } & PLS1 & 0.00395 & $<0.0001$ & 88.46 & 0.905 & 0.0031 \\
\hline & PLS2 & 0.00109 & 0.0201 & 6.78 & 0.842 & 0.0008 \\
\hline
\end{tabular}

PLS: Partial Least Squares; S.v. p-value: permutation test on Singular values; \% Total covar.: Total covariance percent; Correlation: Pearson correlation coefficients between PLS scores of Block 1 and Block 2; Corr. p-value: permutation test on correlation values from the PLS scores.

All tests were significant at 0.05 level after 10000 round permutations, except those tagged by and asterisk. 


\section{Morphological integration}

Species averaged. The PLS analysis on the averaged species (PLSw; Fig. 5) shows that the first two pairs of PLSw explains the $93 \%$ of covariation (Tab. 2) and their shape changes vectors are very similar to those of the two first components of PCAw (angle between vectors: $4.42^{\circ}$ and $21.01^{\circ}$ respectively; both $p<0.00001$ after 10000 rounds of permutation tests). In addition, the PLSw1 vector (88\% of covariation) shows an angle with PC1 of Cassini (2013) of $33.03^{\circ}, \mathrm{p}<0.00001$ as the PCA $w$ (see above).

The PLSw1 vectors were visualized as surface plus thin plate spline gridlines deformations in Figure 5.1. The shape changes associated to the first block (red) ranges from a slender and rostrocaudally elongated symphysis with a low and straight alveolar ramus (on the negative end) to a short and vertically oriented mandibular symphysis with the alveolar ramus being deeper toward the third molar (on the positive end; Fig. 5.1). These shape changes correlate to the following shapes in the second block (blue), which ranges from a less developed coronoid process and masseteric fossa and a relative low position of the condyle (on the negative end) to a more developed coronoid process and masseteric fossa and a high position of the condyle (on the positive end; Fig. 5.1). The PLSw1 scores show a high correlation between blocks ( $r=0.931, p<0.002$ after 10000 rounds of permutation tests). The litopterns and the astrapothere cluster on the double negative quadrant, showing a common pattern of covariation mainly associated to gracile mandibles (Fig. 5.2). Conversely, the notoungulates, whit the exception of Pachyrukhos, lie on the double positive quadrant, but the dimensions displayed a clear distinction between species suggesting a slightly different pattern of covariation in the various families of the order (Fig. 5.2). On the one hand, toxodonts and Protypotherium spp. seem to depart with opposite tendencies from the common pattern of covariation. On the other hand, Pachyrukhos (which clusters with proterotheriids and the astrapothere) and Interatherium share the same covariation pattern of all Santacrucian ungulates.

The PLSw2 vectors were visualized as surface plus thin plate spline gridlines deformations in Figure 5.3. The shape changes associated to the first block (red) ranges from a short, robust and straight alveolar ramus in particular at the
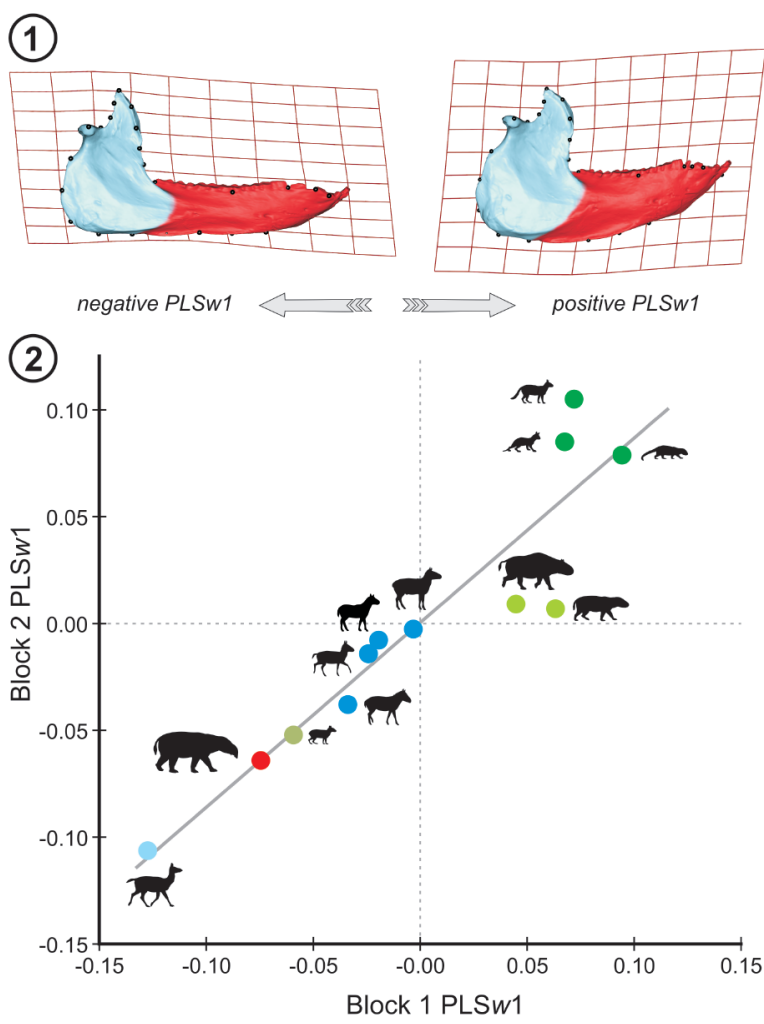

(3)

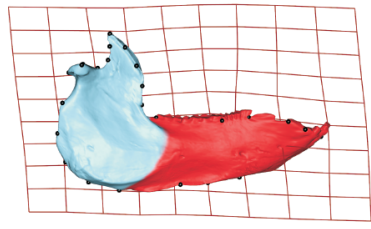

negative PLSw2

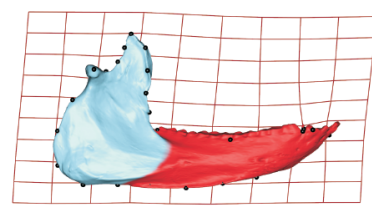

$22 \mathrm{r}$ positive PLSW2

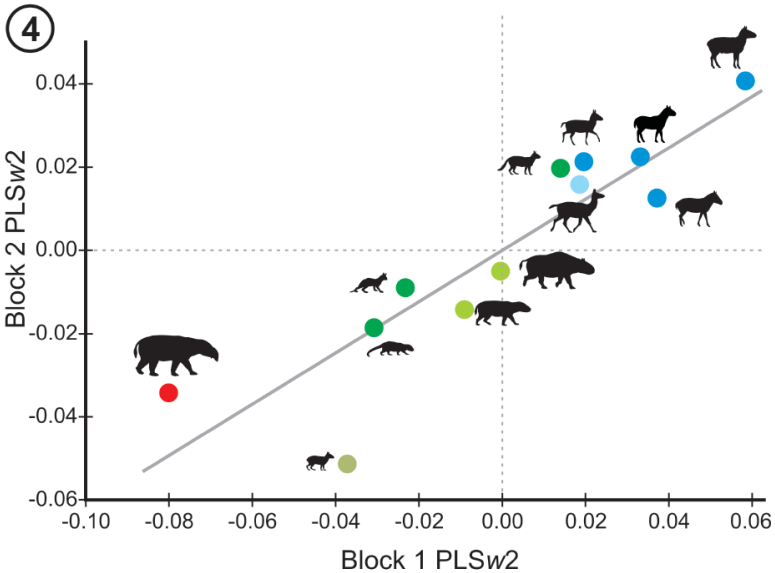

Figure 5. PLSw of Santacrucian ungulate specimens. 1, thin plate spline gridlines of mandibular shape (lateral norm) of negative and positive most first pair of PLS; 2, taxa distribution on the morphospace depicted by the two first PLS dimensions; 3 , thin plate spline gridlines of mandibular shape (lateral norm) of negative and positive most second pair of PLS; 4, taxa distribution on the morphospace depicted by the two second PLS dimensions. Reference: Astrapotheria: red circle, Litopterna: blue range circles, Notoungulata: green range circles; common covariation trend: grey line; silhouettes as in Figure 3. 
postcanine teeth (on the negative end) to long, slender and curved alveolar ramus (on the positive end; Fig. 5.3). These shape changes correlate to the following shapes in the second block (blue): on the negative side by a curved rostral margin of the mandibular angle and coronoid process along the $\mathrm{m}$. temporal insertion, as well as the ventral and caudal margin of the mandibular angle along the m. masseterpterygoid insertion; on the positive side by a more straight rostral margin of the mandibular angle and coronoid process along the m. temporal insertion, as well as the ventral (but not caudal) margin of the mandibular angle along the $\mathrm{m}$. masseter-pterygoid insertion (on the positive end; Fig. 5.1). The PLSw2 scores showed a high correlation between blocks (Fig. 5.4 and Tab. 2; $r=0.898, p<0.0114$ after 10000 rounds of permutation tests). In this morphospace, all litopterns cluster together in the double positive quadrant. All Santacrucian taxa seem to share a common pattern of covariation, with the exception of Pachyrukhos and Astrapotherium, which depart with opposite tendencies.

The RV coefficient for the two proposed contiguous partitions on the averaged species (RV $w$ ) was of 0.784 and only 1442 out of 43634 possible contiguous partitions resulted with $\mathrm{RV} w$ less than the a priori hypothesis given a proportion of 0.033048 .
In the separate fit analysis, the PLS showed that the two first dimensions were significant and explain $~ 73 \%$ of covariation (Tab. 3) and the scores have a high correlation between blocks ( $r=0.851, p<0.0418$ after 10000 rounds of permutation tests). The shape changes vectors of these dimensions were similar but inverted (negative and positive sides) to the corresponding PLSw1 but with less changes on the rostroventral margin of the mandibular symphysis on the first block (Landmarks 1 and 2; supplementary material 01) and in the second block a more reduced coronoid process (Landmarks 11 to 14; supplementary material 01). In the modularity analyses, the RV coefficient (RVwsf) was 0.492 with a $p$-value after 10.000 permutation rounds of 0.0415 (supplementary material 01).

These results keep consistent when repeated on the independent contrast (see supplementary material 01). The PLS analyses on the independent contrast (PLSic) showed that the first dimension explains about $80 \%$ of covariation (Tab. 2) and the scores have a high correlation between blocks ( $r=0.934, p<0.0032$ after 10000 rounds of permutation tests). The shape changes of PLSic1 vectors were similar to the corresponding PLS $w 1$ with an angle between vectors of $21.014^{\circ}$ ( $p<0.00001$ after 10000 rounds of permutation tests). The obtained RV coefficient on the inde-

TABLE 3 - Mandibular Partial Least Squares analyses for each data set using separate fit.

\begin{tabular}{|c|c|c|c|c|c|c|}
\hline Data set & Pair of axes & Singular value & S.v. p-value & \% Total covar. & Correlation & Corr. $p$-value \\
\hline \multirow{2}{*}{ Species a } & PLSwsf1 & 0.00796 & 0.0436 & 73.28 & 0.851 & 0.0418 \\
\hline & PLSwsf2 & 0.00332 * & 0.5613 & 12.73 & $0.683^{*}$ & 0.4249 \\
\hline \multirow{2}{*}{ Independ } & PLSicsf1 & $0,0023 *$ & 0,6486 & 43,033 & $0,681 *$ & 0,829 \\
\hline & PLSicsf2 & $0,00166^{*}$ & 0,38 & 22,422 & $0,831 *$ & 0,1434 \\
\hline \multirow{2}{*}{ Notoungu } & PLSnsf1 & 0.00899 * & 0.2313 & 76.21 & $0.854^{*}$ & 0.1932 \\
\hline & PLSnsf2 & 0.00445 & 0.0427 & 18.66 & $0.830^{*}$ & 0.4721 \\
\hline \multirow[b]{2}{*}{ Litopterno } & PLSIsf1 & $0.00601 *$ & 0.3302 & 77.0 & $0.870 *$ & 0.6492 \\
\hline & PLSIsf2 & $0.00279 *$ & 0.199 & 16.61 & $0.914 *$ & 0.4472 \\
\hline
\end{tabular}

PLS: Partial Least Squares; S.v. p-value: permutation test on Singular values; \% Total covar.: Total covariance percent; Correlation: Pearson correlation coefficients between PLS scores of Block 1 and Block 2; Corr. p-value: permutation test on correlation values from the PLS scores.

All tests were significant at 0.05 level after 10000 round permutations, except those tagged by and asterisk. 
pendent contrasts (RVic) was of 0.771 and 3364 of 43634 possible contiguous partitions resulted with RVic less than the a priori hypothesis given a proportion of 0.079 . In the separate fit analysis, the PLS showed that the two first dimensions explain $\sim 43 \%$ of covariation, but were not significantly correlated (Tab. 3). In addition, the RV coefficient (RVicsf) was 0.379 with a p-value after 10.000 permutation rounds of 0.4387 (supplementary material 01).

Notoungulates. The PLS analyses on notoungulates (PLS $n$ ) shows that the first pairs of PLSn explains the $85 \%$ of covariation (Tab. 2), and their shape changes vectors are similar with the first dimension of averaged species PLSn1 (Fig. 6.1; angle between vectors of $35.36^{\circ}$; $p<0.00001$ ). The PLSn1 scores show a high but not significant correlation between blocks (Fig. 6.2 and Tab. 2); $r=0.88, p=0.202$ after 10000 rounds of permutation tests). The Procrustes corre- lation test (Proc. Corr. $=0.9957 ; p=0.00139$ ) indicates that the morphospace depicted by this pair of PLSn seems to be a subspace from that of averaged species analyses (PLSw). The calculated RV coefficient on notoungulates (RVn) was 0.6788 and only 46 of 43634 possible contiguous partitions resulted with $\mathrm{RV} n$ less than the a priori hypothesis given a proportion of 0.00106 . In the separate fit analysis, the PLS showed that the two first dimensions explain $\sim 76 \%$ of covariation, but were not significantly correlated (Tab. 3). In addition, the RV coefficient (RVnsf) was 0.571 with a pvalue after 10.000 permutation rounds of 0.1468 (supplementary material 01).

Litopterns. The PLS analyses on litopterns (PLS/) shows that the first pairs of PLS/ explains more than $91 \%$ of covariation (Tab. 2), and their shape changes vectors are near similar with the first dimension of averaged species PLS/1 (Fig. 6.3;
(1)

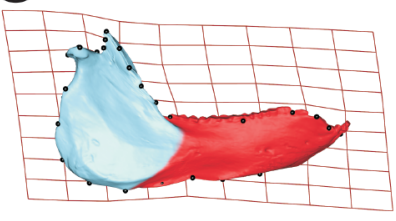

negative PLSn1

(2)
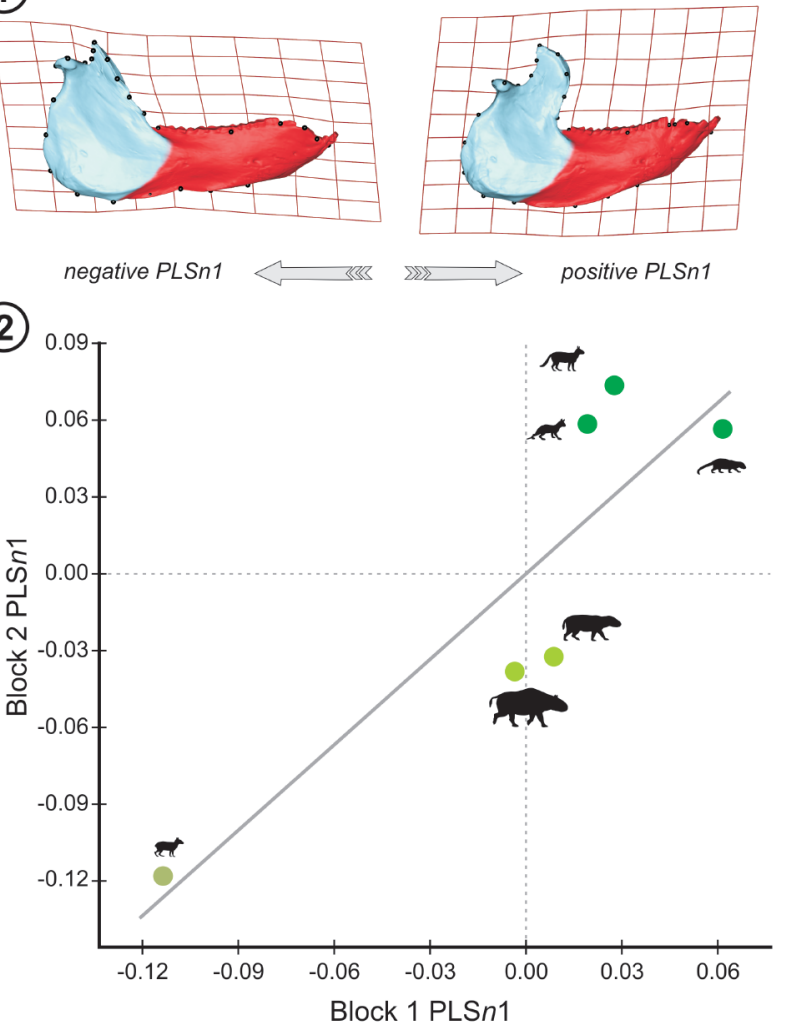

positive PLSn1
(3)

(4)

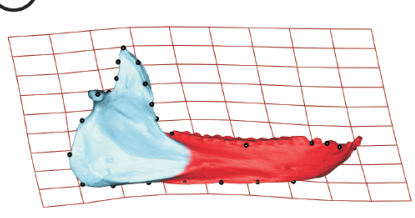

negative PLS/1

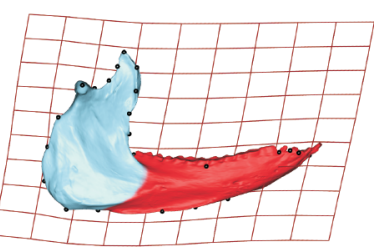

positive PLSI1

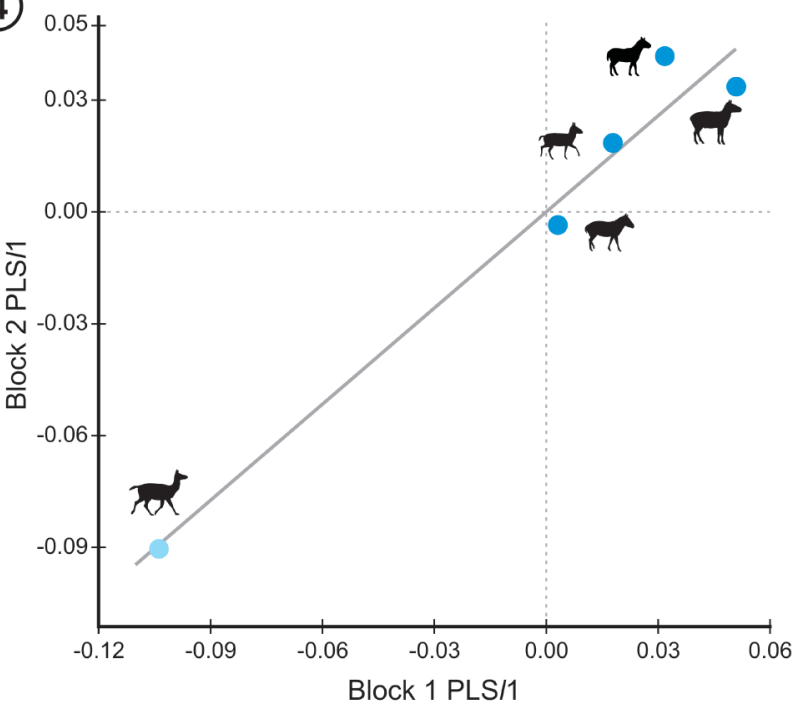

Figure 6. PLSw of Notoungulata and Litopterna subsets. 1, thin plate spline gridlines of notoungulate mandibular shape (lateral norm) of most negative and positive first pair of PLS; 2 , distribution of Notoungulata on the morphospace depicted by the two first PLS dimensions; 3 , thin plate spline gridlines of litoptern mandibular shape (lateral norm) of most negative and positive second pair of PLS; 4, distribution of Litopterna on the morphospace depicted by the two second PLS dimensions. Reference: common covariation trend: grey line; silhouettes as in Figure 3. 
angle between vectors of $\left.36.29^{\circ} ; \mathrm{p}<0.00001\right)$. The PLS/1 scores show an extremely high significant correlation between blocks (Fig. 6.4; $r=0.984, p<0.032$ after 10000 rounds of permutation tests). The Procrustes correlation test (Proc. Corr. $=0.9953 ; \mathrm{p}=0.0083$ ) indicates that the morphospace depicted by this pair of PLS/ seems to be a subspace from that of averaged species analyses (PLSw). The calculated RV coefficient on litopterns (RV/) was 0.95 and as much as 15700 of 43634 possible contiguous partitions resulted with RV/less than the a priori hypothesis given a proportion of 0.3598 . In the separate fit analysis, the PLS showed that the two first dimensions explain $\sim 77 \%$ of covariation, but were not significantly correlated (Tab. 3). In addition, the RV coefficient (RVIsf) was 0.656 with a p- value after 10.000 permutation rounds of 0.3072 (supplementary material 01).

\section{DISCUSSION}

As mentioned above, D'Arcy Thompson (1917) aimed to incorporate mathematics to describe the morphological variation, a "dream [...] now realized" by geometrics morphometrics (Adams et al., 2013: p. 12). The methods of geometric morphometrics are suitable for investigating morphological integration and modularity, an issue already present in Darcy' thoughts: "If [the morphologist] is from time to time constrained to admit the existence of "correlation" between characters [...] yet all the while he recognises this fact of correlation somewhat vaguely" Thompson (1917: p. 1036).

\section{Species variation}

Mandible was of particular interest by paleobiologists because reflects masticatory function better than the cranium (Janis, 1995; Vizcaíno and Bargo, 1998; Bargo and Vizcaíno, 2008; Mendoza and Palmqvist, 2008; Cassini, 2013 and references therein). Despite the fact that our dataset is small and consists only of an average of the best preserved specimens of each species, the results presented here are in general in agreement with those of Cassini (2013). The most evident pattern found was the shape changes associated to slender vs. robust jaws, which seem to be repeated in many ungulate clades, but also in carnivores and xenarthrans (De Esteban-Trivigno, 2011; Fraser and Theodor,
2011; Meloro and O'Higgins, 2011; Cassini, 2013; Echarri and Prevosti, 2015). Results were similar between the PCA of averaged species and independent contrast (i.e., PCA $w$ and P(Aic), in which forms with robust mandible are characterized by an acute angle between the mandibular corpus and the ramus, whereas forms with slender mandibles are characterized by an obtuse angle. According to Cassini (2013), this pattern, as well as the thickness of the mandibular corpus and the length of the diastema between incisors and premolars, reflects allometric scaling.

The notoungulates showed higher morphological disparity than the litopterns. Indeed, it seems to be that most of the whole sample MD index ( 0.0174) is mostly accounted by the notoungulates ( 0.0154). These findings are in accordance with the long-held idea that Notoungulata constitutes the most abundant and diverse clade of endemic South American ungulates, either taxonomically or morphologically as in body size range. In this respect, the Santacrucian notoungulates were not an exception (see Cassini et al., 2012a, and references therein).

\section{Morphological integration}

Following Klingenberg (2008), there is a well-established hypothesis that the mandible consist of two separate functional modules (i.e., alveolar ramus and ascending ramus). In our results, considering the averaged species PLSw analyses, the same PCAw morphological pattern emerged. In addition, the angular comparison of shape change vectors of both analyses (PCAw and PLSw) indicated that the pattern of variation across the entire mandibles is shared with the patterns of covariation between the alveolar-ascending rami. In fact, this is usually associated to a large amount of integration between modules (Klingenberg and Zaklan, 2000). In the morphospace depicted by first dimension of PLSw (Fig. 5.2), it seems clear that this morphological variation-covariation is shared by all the Santacrucian ungulates but nesodontines (Adinotherium and Nesodon) and Protypotherium spp. While in nesodontines departing in covariation pattern is accounted by the alveolar region, in Protypotherium spp. is accounted by the ascending region. It is remarkable that notoungulates, represented here by three families, occupy a larger portion of the covariation morphospace than litopterns. Additionally, the shape 
changes associated to the double negative quadrant of PLSw covariation-morphospace (litopterns, astrapothere plus Pachyrukhos) look more like a modern ungulate (i.e., artiodactyls and perissodactyls) than the double positive quadrant (nesodontines plus interatheriids), which resemble that of hyraxes. Studying the biomechanics of the masticatory apparatus of Santacrucian ungulates, Cassini and Vizcaíno (2012) found similar convergences. While the litopterns resemble the mechanical design of camelids and astrapotheres that of tapirs, only Pachyrukhos, among notoungulates, possesses the characteristic leverage ratio (masseter vs. temporal) of other extant herbivores (i.e., equids).

Testing a priori modularity hypothesis, the RV coefficients using a common shape space were always greater than those using the separate Procrustes fit analysis. This is in agreement with Klingenberg (2009, 2013), because in the first case we evaluate all aspects of covariation (i.e., the structure as a whole) whereas, in the second case, we only deal with the shared shape changes not related to relative size and position of each block (i.e., both blocks taken separately). Besides this difference in RV values, the analyses are mainly consistent when rejecting or not the null hypotheses of integration. In the case of notoungulates, this is contradictory because the analysis based on the common shape space rejects the null hypothesis of integration, whereas the one using the separate Procrustes fit does not. One possible explanation is that, in the common shape space, we deal with the allometric aspects of covariation, particularly the change in the angle between the two rami (e.g., acute angle in the smaller notoungulates and an obtuse angle in the larger ones; see Cassini, 2013). As we wish to consider the interaction between the two blocks, we will discuss only those results related with the common shape space analyses.

Testing a priori modularity hypothesis, the RV w coefficient rejects the null hypothesis of integration (with a marginally significant $p=0.033$ ), contradicting the PLS $w$ results. We could understand this contradiction considering the statement of Klingenberg et al. (2003: p. 530) "modularity in the mandible appears to be a question of degrees, not a blackwhite matter". Alternatively, it could be explained by different tendencies between clades. In fact, the permutation test on the RVic does not allow rejecting the null hypothesis of integration between alveolar-ascending rami. This suggests that these results may be constrained by the phylogenetic history, and must be evaluated at different levels of the taxonomic hierarchy.

The two distinct analytical approaches to evaluate modularity (i.e., PLS and RV) within clades (i.e., litopterns and notoungulates) do not show the aforementioned contradictions. In litopterns, the PLS/ scores shows an extremely high and significant correlation ( $r=0.995 ; p=0.0083$ ) and a high but non-significant observed Escoufier's RV value $(R V I=0.95 ; p=0.36)$, suggesting a strong morphological integration. Conversely, in notoungulates, the PLSn scores show a lower and non-significant correlation $(r=0.88$; $\mathrm{p}=0.202$ ) and a low and significant observed Escoufier's RV value (RVn=0.679; $\mathrm{p}=0.001)$, suggesting evidence of modularity (but see above).

\section{Functional implications}

Previous studies on Santacrucian ungulates paleobiology recall in the role of the morphological traits related to the masticatory muscles (attached to the ascending ramus) and crown height or hypsodonty (related to the alveolar ramus). Litopterns have very similar masticatory muscle architecture and lever arms between them (e.g., the great development of the sagittal crest and origin of the temporal muscle, as well as a great surface available for the insertion of the masseter muscle) and low hypsodonty indices (HI) that ranges from 0.78 to 1.33 (Cassini et al., 2012a; Cassini and Vizcaíno, 2012; Cassini, 2013). Conversely, notoungulates show a different muscle architecture and lever arms between them (e.g., in both nesodontines and interatheriids the temporal is well developed whereas in the hegetotheriid Pachyrukhos it is poorly developed) and high $\mathrm{HI}$, from 3.24 to 7.76, including euhypsodont and protohypsodont (sensu Mones, 1982) taxa (Cassini et al., 2011, 2012a; Cassini and Vizcaíno, 2012; Cassini, 2013). Our results suggest a strong morphological integration in the mandible of litopterns (and perhaps the astrapotheres) and modularity in the notoungulates. The common pattern of covariation found in the astrapotheres and litopterns might be due to similar constraints (developmental, functional and/or biomechanical). It is noteworthy that the two taxa with nasal retraction lie on the 
most negative end of covariation axis of PLSw, associated to a slender mandible. This was also highlighted by Cassini and Vizcaíno (2012). In their study, these authors concluded that Theosodon and Astrapotherium have a gracile masticatory system, unable to have a powerful bite, particularly at the anterior region of the jaw. The modularity present in notoungulates would have allowed different kinds of specializations in the masticatory musculature and the crown height of molars, without a marked morphological constrain. Consequently, this modularity would have permitted the morphological diversification seen in notoungulates, in contrast with the more conservative morphology within litopterns.

As a working hypothesis, we propose that the two functional modules in the mandible (alveolar and ascending rami) must have their counterparts in the cranium. The masticatory muscles and their origin and insertion areas could be modeling shape variation on the ascending ramus and the cranial vault, including the zygomatic arch. At the same time, the crown height and the spaces required for accommodate the teeth could be modeling the alveolar ramus and the rostrum. On the one hand, a strong morphological integration between these two units could drive to more conservative skulls and perhaps a constraining use of resources (e.g., proterotheriids were likely browsers in closed habitats; see Scott (1910); Cifelli and Guerrero (1997); Soria (2001); Villafañe et al. (2006); Cassini et al. (2012a); Cassini (2013) and references therein). On the other hand, a weak morphological integration between these units (i.e., modularity) could relay in a high degree of freedom of morphological change, allowing a large diversification. For example, hypsodonty evolved at least four times within notoungulates (in the toxodontids, interatheriids, mesotheriide and hegetotheriids; Croft and Weinstein, 2008), in parallel with a broad arrange of anatomical traits related to the sensorial organs.

Finally, sharing D'Arcy Thompson's passion for understanding animal forms based on mathematical and physical ideas, we aimed to honor his pioneer work. Today, in the computer era, the analytical study of form help us to detect patterns useful to elucidate the fascinating evolutionary history of the South American endemic ungulates.

\section{CONCLUSIONS}

By the late-early Miocene Santacrucian Age, the two main linages of South American ungulates, litopterns and notoungulates, plus astrapotheres were clearly differentiated and made a different use of food resources. On the available evidence, litopterns and notoungulates present different covariation patterns and strength of association between the two functional units of the mandibles (alveolar and ascending rami). These issues are in concordance with both the higher taxonomic and morphological diversity of the notoungulates, particularly the typotheres. Still remains to be tested whether modularity allows different kinds of specializations in the masticatory musculature and the crown height of cheek teeth, without a marked morphological constrain. However, it is likely that the hypsodonty not only integrates a character complex with tooth oclussal complexity and surface area, but also with mandibular shape. Indeed, as D'Arcy Thompson (1917; p. 1032) pointed out "In a very large part of morphology, our essential task lies in the comparison of related forms rather than in the precise definition of each".

\section{ACKNOWLEDGMENTS}

The authors wish to thank the Dirección de Patrimonio Cultural and Museo Regional Provincial Padre M. J. Molina (Río Gallegos, Argentina); to M. Reguero (MLP), A. Kramarz (MACN), J. Flynn (AMNH) and W. Joyce (YPM) for granting access to the vertebrate paleontological collections. The comments and corrections by the editor Esperanza Cerdeño and the reviewers, Fabio Machado and one anonymous, greatly enhanced this manuscript. This is a contribution to the projects PICT 2013-0143 (ANPCYT) and UNLP N750 to S.F.V., National Science Foundation to R.F. Kay, National Geographic Society to S.F.V and R.F. Kay and UNLu CDD-CB 650/14 to GHC.

\section{REFERENCES}

Adams, D.C., Rohlf, F.J., and Slice, D.E. 2013. A field comes of age: geometric -morphometrics in the 21st century. Hystrix 24: 7-14.

Bargo, M.S., and Vizcaíno, S.F. 2008. Paleobiology of Pleistocene ground sloths (Xenarthra, Tardigrada): biomechanics, morphogeometry and ecomorphology applied to the masticatory apparatus. Ameghiniana 45: 175-196.

Bastir, M., Rosas, A., Stringer, C., Manuel Cuétara, J., Kruszynski, R., Weber, G.W., Ross, C.F., and Ravosa, M.J. 2010. Effects of brain and facial size on basicranial form in human and primate evolution. Journal of Human Evolution 58: 424-431.

Billet, G. 2010. New Observations on the Skull of Pyrotherium (Pyrotheria, Mammalia) and New Phylogenetic Hypotheses on South American Ungulates. Journal of Mammalian Evolution 17: 21-59.

Billet, G. 2011. Phylogeny of the Notoungulata (Mammalia) based 
on cranial and dental characters. Journal of Systematic Palaeontology 9: 481-497.

Billet, G., Blondel, C., and de Muizon, C. 2009. Dental microwear analysis of notoungulates (Mammalia) from Salla (Late Oligocene, Bolivia) and discussion on their precocious hypsodonty. Palaeogeography, Palaeoclimatology, Palaeoecology 274: 114-124.

Cardini, A., and Loy, A. 2013. On growth and form in the "computer era": from geometric to biological morphometrics. Hystrix $24:$ $1-5$.

Cassini, G.H. 2013. Skull geometric morphometrics and paleoecology of Santacrucian (late early Miocene; Patagonia) native ungulates (Astrapotheria, Litopterna, and Notoungulata). Ameghiniana 50: 193-216.

Cassini, G.H., Cerdeño, M.E., Villafañe, A.L., and Muñoz, N.A. 2012 a. Paleobiology of Santacrucian native ungulates (Meridiungulata: Astrapotheria, Litopterna and Notoungulata. In: S.F. Vizcaíno, R. Kay, and M.S. Bargo, (Eds.), Early Miocene Paleobiology in Patagonia: high-latitude paleocommunities of the Santa Cruz Formation. Cambridge University Press, p. 243-286.

Cassini, G.H., Hernández Del Pino, S., Muñoz, N.A., Acosta, M.V.W.G., Fernández, M., Bargo, M.S., and Vizcaíno, S.F. 2017. Teeth complexity, hypsodonty and body mass in Santacrucian (Early Miocene) notoungulates (Mammalia). Earth and Environmental Science Transactions of the Royal Society of Edinburgh 106: 303313.

Cassini, G.H., Mendoza, M., Vizcaíno, S.F., and Bargo, M.S. 2011. Inferring habitat and feeding behaviour of early Miocene notoungulates from Patagonia. Lethaia 44: 153-165.

Cassini, G.H., and Vizcaíno, S.F. 2012. An Approach to the Biomechanics of the Masticatory Apparatus of Early Miocene (Santacrucian Age) South American Ungulates (Astrapotheria, Litopterna, and Notoungulata): Moment Arm Estimation Based on 3D Landmarks. Journal of Mammalian Evolution 19: 9-25.

Cassini, G.H., Vizcaíno, S.F., and Bargo, M.S. 2012b. Body mass estimation in Early Miocene native South American ungulates: a predictive equation based on 3D landmarks. Journal of Zoology 287: 53-64.

Cifelli, R.L., and Guerrero, J.G. 1997. Litopterns. In: R.F. Kay, R.H. Madden, R.L. Cifelli, and J.J. Flynn (Eds.), Vertebrate Paleontology in the Neotropics: The Miocene Fauna of La Venta, Colombia. Smithsonian Institution Press, Washington, DC, p. 289-302.

Croft, D.A. 1999. Placentals: endemic South American ungulates. In: R. Singer (Ed.), The Encyclopedia of Paleontology. FitzroyDearborn, Chicago, p. 890-906.

Croft, D.A. 2001. Cenozoic environmental change in South America as indicated by mammalian body size distributions (cenograms). Diversity and Distributions 7: 271-287.

Croft, D.A., and Anderson, L.C. 2008. Locomotion in the extinct notoungulate Protypotherium. Palaeontologia Electronica 11: 1-20.

Croft, D.A., and Weinstein, D. 2008. The first application of the mesowear method to endemic South American ungulates (Notoungulata). Palaeogeography, Palaeoclimatology, Palaeoecology 269: 103-114.

Darwin, C. 1845. The voyage of the Beagle. Journal of researches into the natural history and geology of the countries visited during the voyage of H.M.S. Beagle around the world, under the command of Capt. Fitz Roy, R.A. Murray, London, 536 p.

De Esteban-Trivigno, S. 2011. Ecomorfología de Xenartros extintos: análisis de la mandíbula con métodos de morfometría geométrica. Ameghiniana 48: 381-398.

Drake, A.G., and Klingenberg, C.P. 2008. The pace of morphological change: historical transformation of skull shape in St Bernard dogs. Proceedings of the Royal Society 275: 71-76.

Drake, A.G., and Klingenberg, C.P. 2010. Large-Scale Diversification of Skull Shape in Domestic Dogs: Disparity and Modularity. The American Naturalist 175: 289-301.

Echarri, S., and Prevosti, F.J. 2015. Differences in mandibular disparity between extant and extinct species of metatherian and placental carnivore clades. Lethaia 48: 196-204.

Elissamburu, A. 2004. Análisis morfométrico y morfofuncional del esqueleto apendicular de Paedotherium (Mammalia, Notoungulata). Ameghiniana 41: 363-380.

Elissamburu, A. 2010. Estudio biomecánico y morfofuncional del esqueleto apendicular de Homalodotherium Flower 1873 (Mammalia, Notoungulata). Ameghiniana 47: 25-43.

Elissamburu, A. 2012. Estimación de la masa corporal en géneros del Orden Notoungulata. Estudios Geológicos 68: 91-111.

Fraser, D., and Theodor, J.M. 2011. Comparing ungulate dietary proxies using discriminant function analysis. Journal of Morphology 272: 1513-1526.

Giannini, N.P., and García-López, D.A. 2014. Ecomorphology of Mammalian Fossil Lineages: Identifying Morphotypes in a Case Study of Endemic South American Ungulates. Journal of Mammalian Evolution 21: 195-212.

Gomes Rodrigues, H., Herrel, A., and Billet, G. 2017. Ontogenetic and life history trait changes associated with convergent ecological specializations in extinct ungulate mammals. Proceedings of the National Academy of Sciences 114: 1069-1074.

Janis, C.M. 1995. Correlations between craniodental morphology and feeding behavior in ungulates: Reciprocal illumination between living and fossil taxa. In: J.J. Thomason (Ed.), Functional Morphology in Vertebrate Paleontology. Cambridge University Press, Cambridge, p. 76-98.

Klingenberg, C.P. 2008. Morphological Integration and Developmental Modularity. Annual Review of Ecology, Evolution, and Systematics 39: 115-132.

Klingenberg, C.P. 2009. Morphometric integration and modularity in configurations of landmarks: tools for evaluating a priori hypotheses. Evolution \& Development 11: 405-421.

Klingenberg, C.P. 2011. MorphoJ: an integrated software package for geometric morphometrics. Molecular Ecology Resources 11: 353-357.

Klingenberg, C.P. 2013. Cranial integration and modularity: insights into evolution and development from morphometric data. Hystrix 24: 16.

Klingenberg, C.P., and Marugán-Lobón, J. 2013. Evolutionary Covariation in Geometric Morphometric Data: Analyzing Integration, Modularity, and Allometry in a Phylogenetic Context. Systematic Biology 62: 591-610.

Klingenberg, C.P., Mebus, K., and Auffray, J.C. 2003. Developmental integration in a complex morphological structure: how distinct are the modules in the mouse mandible? Evolution \& Development 5: 522-531.

Klingenberg, C.P., and Zaklan, S.D. 2000. Morphological integration between developmental compartiments in the Drosophila wing. Evolution 54: 1273-1285.

Maddison, W.P. 1991. Squared-Change Parsimony Reconstructions of Ancestral States for Continuous-Valued Characters on a Phylogenetic Tree. Systematic Biology 40: 304-314.

Manly, B.F.J. 2006. Randomization, Bootstrap, and Monte Carlo methods in biology. Chapman \& Hall/CRC London, $480 \mathrm{p}$.

Mayr, E. 1982. The growth of biological thought: Diversity, evolution, and inheritance. Harvard University Press, Cambridge, 992 p. 
Meloro, C., and O'Higgins, P. 2011. Ecological Adaptations of Mandibular Form in Fissiped Carnivora. Journal of Mammalian Evolution 18: 185-200.

Mendoza, M., and Palmqvist, P. 2008. Hypsodonty in ungulates: An adaptation for grass consumption or for foraging in open habitat? Journal of Zoology 274: 134-142.

Mitteroecker, P., and Bookstein, F. 2008. The evolutionary role of modularity and integration in the hominoid cranium. Evolution 62: 943-958.

Mones, A. 1982. An equivocal nomenclature: What means hypsodonty? Paläontologische Zeitschrift 56: 107-111.

Muñoz, N.A., Cassini, G.H., Candela, A.M., and Vizcaíno, S.F. 2017. Ulnar articular surface 3-D landmarks and ecomorphology of small mammals: a case study of two early Miocene typotheres (Notoungulata) from Patagonia. Earth and Environmental Science Transactions of the Royal Society of Edinburgh 106: 315-323.

Nasif, N.L., Musalem, S., and Cerdeño, E. 2000. A new toxodont from the late Miocene of Catamarca, Argentina, and a phylogenetic analysis of the Toxodontidae. Journal of Vertebrate Paleontology 20: 591-600.

Oksanen, J., Blanchet, F.G., Friendly, M., Kindt, R., Legendre, P., McGlinn, D., Minchin, P.R., O'Hara, R.B., Simpson, G.L., Solymos, P., Stevens, M.H.H., Szoecs, E., and Wagner, H. 2017. Vegan: Community Ecology Package 2: 4-3.

Quenouille, M.H. 1956. Notes on bias in estimation. Biometrika 43: 353-360.

R Development Core Team 2017. R: A language and environment for statistical computing. Vienna, Austria, R Foundation for Statistical Computing.

Reddy, D.P., Kim, J., and Raaum, R. 2007. Resample.exe. http://pages.nycep.org/nmg/programs.html.

Reguero, M.A., and Prevosti, F.J. 2010. Rodent-like notoungulates (Typotheria) from Gran Barranca, Chubut Province, Argentina: phylogeny and systematics. In: R.H. Madden, A.A. Carlini, M.G. Vucetich, and R.F. Kay (Eds.), The Paleontology of Gran Barranca: Evolution and Environmental Change through the Middle Cenozoic of Patagonia. Cambridge University Press, Cambridge, p. 148-165.

Rensberger, J.M., and Pfretzschner, H.U. 1992. Enamel structure in astrapotheres and its functional implications. Scanning Microscopy 6: 495-510.

Riggs, E.S. 1935. A skeleton of Astrapotherium. Geological series of Field Museum of Natural History 6: 167-177.

Rohlf, F.J. 1990. Rotational fit (Procrustes) methods. In: F.J. Rohlf, and F.L. Bookstein (Eds.), Proocedings of the Michigan Morphometrics Workshop. University of Michigan Museum of Zoology, Special Publication $N^{\circ} 2$, Michigan, p. 227-236.

Scarano, A.C., Carlini, A.A., and Illius, A.W. 2011. Interatheriidae (Typotheria: Notoungulata), body size and paleoecology characterization. Mammalian Biology 76: 109-1114.

Scott, W.B. 1910. Mammalia of the Santa Cruz beds. Part I. Litopterna. In: W.B. Scott (Ed.), Reports of the Princeton University Expeditions to Patagonia, 1896-1899. e Princeton University, Princeton, $156 \mathrm{p}$.

Scott, W.B. 1937. A history of land mammals in the Western Hemisphere. Macmillan New York, 786 p.

Schlager, S. 2017. Morpho and Rvcg - Shape Analysis in R. In: G. Zheng, S. Li, and G. Szekely (Eds.), Statistical Shape and Deformation Analysis. Academic Press, London, p. 217-256.

Schmidt, G.I. 2015. Actualización sistemática y filogenia de los Proterotheriidae (Mammalia, Litopterna) del "Mesopotamiense" (Mioceno tardío) de Entre Ríos, Argentina. Revista Brasileira de Paleontología 18: 521-546.
Soria, M.F. 2001. Los Proterotheriidae (Litopterna, Mammalia), sistemática, origen y filogenia. Monografías del Museo Argentino de Ciencias Naturales 1: 1-167.

Thompson, D.A.W. 1917. On growth and form. Cambrige University Press, Cambrige, $1116 \mathrm{p}$.

Townsend, K.E.B., and Croft, D.A. 2008. Diets of notoungulates from the Santa Cruz Formation, Argentina: New evidence from enamel microwear. Journal of Vertebrate Paleontology 28: 217-230.

Villafañe, A.L., Ortiz-Jaureguizar, E., and Bond, M. 2006. Cambios en la riqueza taxonómica y en las tasas de primera y última aparición de los Proterotheriidae (Mammalia, Litopterna) durante el Cenozoico. Estudios Geológicos 62: 155-166.

Vizcaíno, S.F., and Bargo, M.S. 1998. The masticatory apparatus of Eutatus (Mammalia, Cingulata) and some allied genera. Evolution and paleobiology. Paleobiology 24: 371-383.

Vizcaíno, S.F., Bargo, M.S., Cassini, G.H., and Toledo, N. 2016. Forma y función en paleobiología de vertebrados. Editorial de la Universidad Nacional de La Plata (EDULP), 268 p.

Vizcaíno, S.F., Bargo, M.S., Kay, R.F., Fariña, R.A., Di Giacomo, M., Perry, J.M.G., Prevosti, F.J., Toledo, N., Cassini, G.H., and Fernicola, J.C. 2010. A baseline paleoecological study for the Santa Cruz Formation (late-early Miocene) at the Atlantic coast of Patagonia, Argentina. Palaeogeography, Palaeoclimatology, Palaeoecology 292: 507-519.

Vizcaíno, S.F., Kay, R. and Bargo, M.S. 2012. Early Miocene Paleobiology in Patagonia: high-latitude paleocommunities of the Santa Cruz Formation. Cambridge University Press, Cambridge, $370 \mathrm{p}$.

Welker, F., Collins, M.J., Thomas, J.A., Wadsley, M., Brace, S., CappeIlini, E., Turvey, S.T., Reguero, M., Gelfo, J.N., Kramarz, A., Burger, J., Thomas-Oates, J., Ashford, D.A., Ashton, P.D., Rowsell, K., Porter, D.M., Kessler, B., Fischer, R., Baessmann, C., Kaspar, S., Olsen, J.V., Kiley, P., Elliott, J.A., Kelstrup, C.D., Mullin, V., Hofreiter, M., Willerslev, E., Hublin, J.J., Orlando, L., Barnes, I., and MacPhee, R.D.E. 2015. Ancient proteins resolve the evolutionary history of Darwin's South American ungulates. Nature 522: 81-84.

Wilson, L.A.B. 2013. Allometric disparity in rodent evolution. Ecology and Evolution 3: 971-984.

Zelditch, M.L., Swiderski, D.L., Sheets, D.L., and Fink, W.L. 2004. Geometric morphometrics for biologists: a primer. Elsevier Academic Press, London, 443 p.

Doi: 10.5710/PEAPA.07.12.2017.253

Recibido: 15 de octubre 2017

Aceptado: 7 de diciembre 2017 


\section{APPENDIX I}

List of Santacrucian ungulate mandibles examined in this work including taxonomic identifications and collection numbers.

Notoungulata. Toxodontia (Toxodontidae): Adinotherium ovinum MACN-SC 4355. Nesodon imbricatus AMNH 9510; MACN-A 5145; YPM-VPPU 15256, 15336. Typotheria, Interatheriidae: Interatherium robustum MPM-PV 3469, 3471; YPM-VPPU 15100, 15554. Protypotherium australe AMNH 9565. Protypotherium attenuatum MPM-PV 3556*. Hegetotheriidae: Pachyrukhos moyani AMNH 9219.

Litopterna. Proterotheriidae: Anisolophus australis YPMVPPU 15996. Diadiaphorus majusculus MPM-PV 3397. Tetramerorhinus mixtum MACN-A 8971. Thoatherium minusculum YPM-VPPU 15719. Macraucheniidae: Theosodon garretorum YPM-VPPU 15164.

Astrapotheria. Astrapotheriidae: Astrapotherium magnum AMNH 9278.

* missasigned as 3959 in Cassini (2013). 